\title{
Metastasis of ovarian cancer is mediated by kallikrein related peptidases
}

\author{
Ying Dong • Daniela Loessner $\cdot$ Helen Irving-Rodgers • \\ Andreas Obermair · James L. Nicklin • \\ Judith A. Clements
}

Received: 10 July 2013/Accepted: 26 August 2013/Published online: 17 September 2013

(C) The Author(s) 2013. This article is published with open access at Springerlink.com

\begin{abstract}
Ovarian cancer, in particular epithelial ovarian cancer (EOC), is commonly diagnosed when the tumor has metastasized into the abdominal cavity with an accumulation of ascites fluid. Combining histopathology and genetic variations, EOC can be sub-grouped into Type-I and Type-II tumors, of which the latter are more aggressive and metastatic. Metastasis and chemoresistance are the key events associated with the tumor microenvironment that lead to a poor patient outcome. Kallikrein-related peptidases (KLKs) are aberrantly expressed in EOC, in particular, in the more metastatic Type-II tumors. KLKs are a family of 15 serine proteases that are expressed in diverse human tissues and involved in various patho-physiological processes. As extracellular enzymes, KLKs function in the
\end{abstract}

Y. Dong $(\bowtie) \cdot$ D. Loessner $\cdot$ H. Irving-Rodgers .

J. A. Clements

Cancer Program, Institute of Health and Biomedical Innovation, Queensland University of Technology, 60 Musk Avenue, Kelvin Grove, Brisbane, QLD 4059, Australia

e-mail: y.dong@qut.edu.au

Y. Dong · D. Loessner · H. Irving-Rodgers - J. A. Clements Translational Research Institute, 37 Kent Street, Wooloongabba, QLD 4102, Australia

Present Address:

H. Irving-Rodgers

School of Medical Science, Griffith University, Gold Coast

Campus, Southport, QLD 4222, Australia

\section{A. Obermair}

Department of Gynaecological Oncology, Royal Women's Hospital, Herston, QLD 4101, Australia

\section{J. L. Nicklin}

Department of Gynaecological Oncology, Wesley Research Institute, Auchenflower, QLD 4066, Australia hydrolysis of growth factors, proteases, cell membrane bound receptors, adhesion proteins, and cytokines initiating intracellular signaling pathways and their downstream events. High KLK levels are differentially associated with the prognosis of ovarian cancer patients, suggesting that they not only have application as biomarkers but also function in disease progression, and therefore are potential therapeutic targets. Recent studies have demonstrated the function of these proteases in promoting and/or suppressing the invasive behavior of ovarian cancer cells in metastasis in vitro and in vivo. Both conventional cell culture methods and three-dimensional platforms have been applied to mimic the ovarian cancer microenvironment of patients, such as the solid stromal matrix and ascites fluid. Here we summarize published studies to provide an overview of our understanding of the role of KLKs in EOC, and to lay the foundation for future research directions.

Keywords Kallikrein-related peptidases - Serous ovarian cancer - Ascites microenvironment .

Multicellular aggregation $\cdot$ Chemoresistance .

Metastasis

\section{Introduction}

Ovarian cancer represents a growing women's health issue worldwide [1-3]. In Australia, the risk of a female being diagnosed with ovarian cancer is 1 in 79 [1]. While the agestandardized incidence rate of ovarian cancer is decreasing, the actual number of women diagnosed with ovarian cancer in Australia is increasing and is projected to increase further due to the ageing of the population. In the US, 22,240 new cases will be diagnosed and 14,030 women will die from this cancer in 2013 [3]. The majority of ovarian 
cancers are classified as epithelial ovarian cancers (EOC, $\sim 90 \%$ ) with the patients' mean age at 62 years. Given the lack of early warning signs and the lack of effective screening, three quarters of patients with epithelial ovarian cancer (EOC) are diagnosed at advanced stages 3 or 4, thus implying spread throughout the peritoneal lining, parenchyma of the liver or pleura [4]. Treatment comprises a combination of aggressive surgery plus cytotoxic chemotherapy [5]. Morbidity of treatment is considerable and prognosis remains typically poor worldwide [1-3]. While most patients respond to chemotherapy initially, the tumor eventually becomes chemo-resistant which leads to relapse [6], with an average disease progression free survival of 18 months [7] and a less than $30 \%$ 5-year overall survival rate [8]. By contrast, survival outcomes are generally good for women diagnosed with non-epithelial ovarian cancer or with EOC incidentally found at an early stage.

In the past three decades, our understanding of EOC has been extended into its origin, classification and genetic features. Studies on the characterization of metastasis of ovarian cancer have led to the search for new biological agents as part of therapeutic regimens. It is well known that metastasis is associated with the invasive behaviors of tumor cells in which cell membrane proteins, receptors and extracellular matrix (ECM) proteins play important roles [6]. As in other cancer types, cancer-associated proteases are a crucial component in the regulation of these proteins via hydrolysis, such as matrix metalloproteinase (MMP)2, MMP7, MMP9 and urokinase plasminogen activator (uPA) [9-11]. Recent studies have revealed that most kallikreinrelated peptidases (KLKs), a family of serine proteases, are aberrantly expressed in cultured ovarian cancer cells and patient specimens and may also play a role in cancer progression and in particular metastasis $[12,13]$. In the following sections, we will focus on the pathogenesis of EOC, the expression and function of KLKs in EOC, and the challenges faced in the treatment of this cancer.

\section{Pathogenesis of EOC}

The normal ovary is covered by a single layer of flat or cuboidal mesothelial cells. It has been hypothesized that EOCs originate from these ovarian surface mesothelial cells. EOC has been recognized as a heterogeneous and complex disease with predominant serous, mucinous, clear cell, endometrial and transitional cell types. However, recent studies have revealed more genetic and molecular phenotypes that help us better understand the clinical features as listed below.

Challenging the conventional hypothesis, recent pathological studies have proposed that ovarian cancer might in fact generate from seeding of cancer cells from the fallopian tube to the ovary [14-17]. With combined analysis of clinical, histopathological and genetic characteristics, Kurman and colleagues $[17,18]$ have proposed a two-pathway model of this tumor. In particular, they accounted for the difference of mutation frequencies of KRAS, BRAF and TP53 dividing EOC into two categories, Type-I and Type-II tumors. Type-I tumors include serous, endometrioid, mucinous, and clear cell types, but display low-grade nuclear and architectural features, slow growth, and can be associated with well-defined benign and borderline (low malignant potential) ovarian precursor lesions. Most often genetic variations of Type-I tumors are KRAS and $B R A F$ mutations that activate the mitogen-activated protein kinase (MAPK) signaling pathway [19-21]. Additionally, Type-I tumors are more frequently found with mutations of $A R I D 1 A, E R B B 2$, PTEN, CTNNB1 and PIKCA [22]. On the other hand, these alterations are rarely seen in Type-II tumors which are frequently ( $>80 \%$ of cases) detected with mutations of TP53, CCNE1 and chromosome instability [17, 22]. Type-II tumors are rarely linked to benign or borderline ovarian precursor lesions, but comprise almost all of high grade serous EOC, with clinical features of a high growth rate, metastasis and a less than $30 \%$ 5-year patient survival rate [23]. Using integrated genomic analyses, these Type-II tumours and in particular the high grade serous EOCs are subdivided into differentiated, immunoreactive, mesenchymal and proliferative groups due to their different gene signatures [24].

Relevant to ovarian cancer metastasis, and critically due to the lack of an anatomical barrier around the ovary and exposure to the peritoneal space, individual EOC cells or small cell clusters are shed from the primary tumor into the abdominal cavity. These tumor cells adhere to and disrupt the peritoneal mesothelial cells, exposing the Type-I/III collagen-rich ECM underneath the peritoneal membrane. The EOC cells adhere strongly to the exposed ECM, in comparison to the mesothelial cells which adhere more strongly to the interstitial Type-I collagen [25]. Another clinical feature indicative of a poor prognosis for patients with this malignancy, in particular high grade serous EOC, is the formation of ascites fluid [26]. More than $70 \%$ of EOC patients, in particular those with Type-II tumors, present with a pool of fluid in their abdominal cavity (ascites/effusions) harboring a population of tumor cells [26]. This is due to obstruction of lymphatic vessels by implanted tumor, preventing the outflow of fluid that leaks from disorganized tumor vessels and thus accumulating ascites [27]. In this scenario, patients with the aggressive Type-II tumors, in particular high grade serous EOCs, not only have metastatic tumors that grow in solid stromal matrices but also a cell population suspended in the ascites fluid [4, 6, 28]. Similar to the tumor cells in the solid matrices of the metastatic sites, the EOC cells derived from ascites fluid are resistant to various therapeutic regimes [28]. In particular, a recent study demonstrated that a 
subpopulation of EOC cells expressing CA125, EpCAM and STAT3, is able to grow as three dimensional (3D) suspension spheroids or multicellular aggregates (MCAs) that are tumorigenic and resistant to chemo-treatment [29]. These CA125, EpCAM and STAT3 positive ascitic EOC cells are the source of peritoneal adhesions leading to a poor outcome of women diagnosed with this disease. However, the mechanisms underlying metastasis to the peritoneal membrane remain to be elucidated.

\section{Kallikrein-related peptidases (KLKs)}

The kallikrein locus, with 15 members in this family, spans approximately $265 \mathrm{~kb}$ on chromosome 19q13.3-13.4 forming the largest continuous cluster of human proteases (Fig. 1a) [30-34]. Each KLK gene contains $5^{\prime}$ and $3^{\prime}$ untranslated region, 4 introns and 5 exons encoding each of the KLKs (Fig. 1a, b). The KLKs are synthesized as prepro-peptidases, with the pre-signal peptide crucial for secretion of these enzymes (Fig. 1b). Cleavage of the propeptide is required for activation to the mature enzyme with appropriate conformation of the catalytic triad, histidine (His), aspartate (Asp) and serine (Ser). Members of the KLK family have trypsin or chymotrypsin-like substrate specificity. KLK1, KLK2, KLK4-KLK6, and KLK10-KLK15 have trypsin-like specificity for cleavage after argine and lysine residues [35, 36]. KLK15 also has trypsin-like specificity but cleaves after a glutamate residue [37]. On the other hand, KLK3 and KLK7 display chymotrypsin-like specificity for tyrosine, leucine, and phenylalanine residues [13, 38]. Given this specificity and that most KLKs require an enzyme with trypsin-like specificity for activation, it is not surprising that KLK activation cascades can occur in many tissues [13, 39, 40]. It has also been documented that KLKs can be activated by other proteases with a recent biochemical study showing that matrix MMP20 cleaves pro-KLK1-4, pro-KLK6, proKLK7, pro-KLK9, pro-KLK11 and pro-KLK15 [41].

Like other serine proteases, once KLKs are activated, their proteolytic action is irreversible and controlled by endogenous inhibitors [42]. The endogenous inhibitors targeting distinct KLKs have been identified, such as zinc ions, Kazal-type inhibitors and a2-microglobulin [43, 44]. Recently, the naturally occurring 14 residue long cyclic sunflower trypsin inhibitor (SFTI of the Bowman-Birk family) was redesigned to inhibit specific kallikreins using a combination of molecular modeling and matrix substrate screening [45]. SFTI-FCQR selectively blocks the proteolytic activity of KLK4 and reduces the activity of the proteinase activator receptor (PAR)2, a KLK4 substrate, in a cell-based assay [45]. In addition, the SFTI-FCQR Asn14 variant can also inhibit KLK4, and importantly, this variant displayed bioactivity in an in vivo mouse model [46]. Using a similar approach, SFTI-WCTF was selected to potently inhibit KLK7 proteolytic activity at a nanomolar concentration [47].

From a clinically relevant aspect, tissue-specific association of KLKs has been identified. For instance, KLK2, prostate-specific antigen (PSA)/KLK3, KLK4 and KLK11
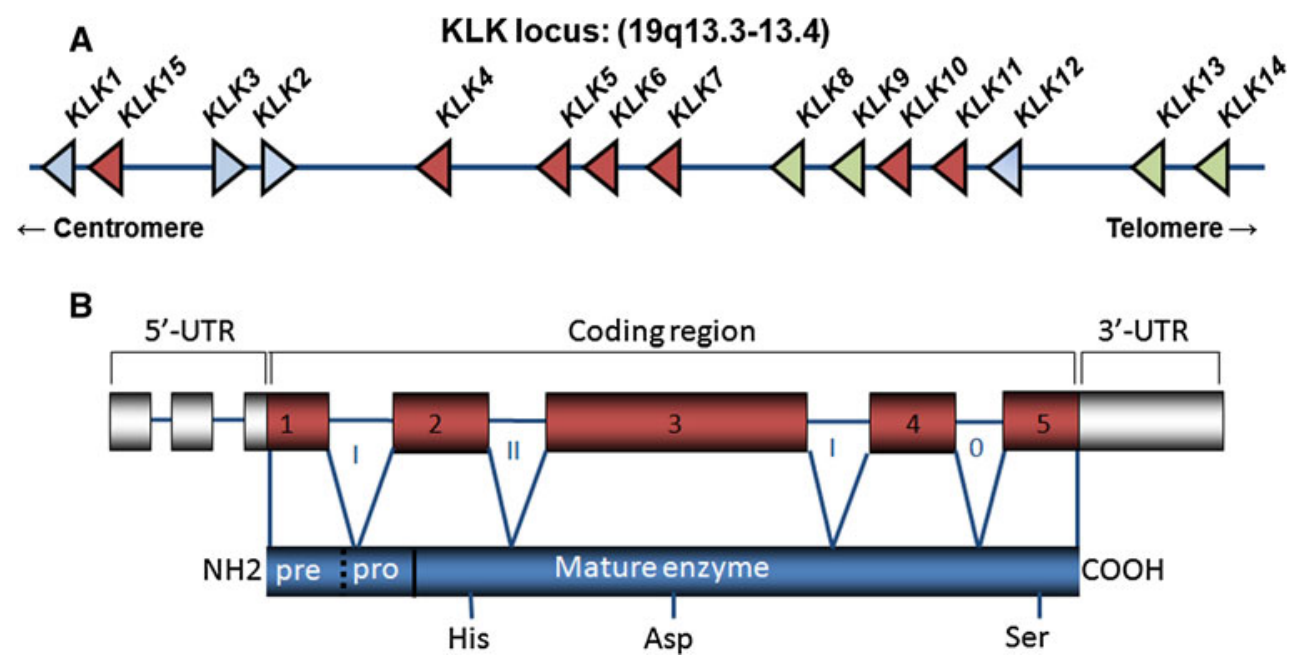

Fig. 1 Genes and exon/intron organization of kallikrein-related peptidases. a Location of the KLK locus at chromosome 19q13.313.4. Schematic representation of the interval between D19S425 and D193418. The KLK locus is located proximal to D19S418. The position of the 15 kallikrein encoding genes on the KLK locus is marked. KLK1, KLK15, to KLK14 are transcribed telomere to centromere, whereas KLK2 and KLK3 are transcribed in the opposite direction. KLKs highlighted in dark red are representative of their aberrant expression associated with poor outcome for ovarian cancer patients, while green indicates an association with favorable patient outcome. b Schematic showing the organization of $5^{\prime}$-untranslated region (5'-UTR), coding region (exons and introns), and $3^{\prime}$-UTR of KLKs (top panel) and KLK protein structure (bottom panel). Catalytic triad, His, Asp and Ser, as indicated 
are expressed at higher levels in prostate tissue extracts and seminal fluid, KLK5-11 in skin, and KLK6 and KLK8 in cerebrospinal fluid [48] where the activation cascades noted above can occur. It has become evident that expression of many KLKs is regulated by steroid hormones in a tissue-specific manner, such as KLK2, PSA/KLK3 and KLK4 by androgen in prostate and breast cancer cells, and KLK4 by estrogen in endometrial and ovarian cancer cells [49-52].

\section{Patho-physiological roles of KLKs}

It has been well documented that KLK enzymes have extracellular hydrolysis activities, such as activating and/or degrading their substrates, including growth factors, ECM proteins, other cancer-associated proteases, cell membrane bound receptors and adhesion proteins. Just as KLK family members have a diverse tissue/organ expression profile, they also have a wide range of physiological functions. For example, KLK1 has a role in the cardiovascular system via cleavage of the low molecular weight kininogen to generate bradykinin, which stimulates its receptor, the bradykinin receptor 2 [53]. KLK4 is involved in the remodeling of the organic matrix and disruption of intercellular junctions in tooth development via hydrolysis of enamelin [54, 55] and amelogenin [56]. KLK4 can also activate pro-meprin $\beta$ and may have a role in keratinocyte migration in skin [57]. In addition to KLK4, a recent study has identified that KLK5 and KLK8 cleave meprins, suggesting their role in this process, and interestingly, KLK5 can also cleave the other subunit of the family, pro-meprin $\alpha$ [58]. KLK5 and KLK7 are involved in keratinization, stratum corneum formation, turnover and desquamation of the skin, via degradation of the cell adhesion glycoproteins, corneodesmosin and plakoglobin [59-61]. These two enzymes have also been localized to numerous other tissues, and their function via hydrolysis to degrade cell membrane bound adhesion glycoproteins, has been found in these organs. KLK6 can hydrolyze the amyloid precursor protein, which is important in the deposition of amyloid plaques and regulation of neural plasticity [62-64]. KLK6 also cleaves myelin basic protein in oligodendrocytes and Schwann cells in the central nervous system in a manner that is related to demyelinating diseases, such as multiple sclerosis [65]. These studies provide evidence that KLK enzymes play a role in diverse patho-physiological processes in human.

PSA/KLK3, a member of KLK gene family, is a well established and clinically-used biomarker for prostate cancer [66]. Recent studies have associated the function of KLKs with the progression of human cancer. Both KLK2 and PSA/KLK3 degrade insulin growth factor binding protein (IGFBP)2, IGFBP3, IGFBP4 and IGFBP 5, thereby releasing the insulin growth factor-1 (IGF1) and regulating the survival and proliferation of both normal and cancerous prostate cells $[67,68]$. KLK4 can activate other enzymatic pathways, e.g. MMP [69], pro-uPA to uPAwhich binds to its receptor uPAR [70]. Interestingly, however, uPAR can be cleaved by KLK4 leading to inactivation of this receptor [70]. Hence, KLK4 is an important mediator of the uPA/ uPAR axis which is known to have an important role in cancer invasion [71, 72]. A recent study shown that KLK7 cleaves proMMP9 generating an active MMP9 fragement but not by other proteases [69]. More recent studies have demonstrated that several KLKs activate a family of G-protein coupled receptors, PARs. For example, PAR1 is activated by KLK1, KLK4-6 and KLK14, PAR2 by KLK2, KLK4-6 and KLK14, and PAR4 by KLK1 and KLK6, leading to the activation of downstream signaling pathways [73-75]. We and others have shown that cleavage of PAR2 by KLK4 activates the MAPK signaling pathway leading to the growth of prostate and colon cancer cells [76, 77]. KLK7 induces shedding of the cell adhesion protein E-Cadherin, uPAR and ECM protein, vitronectin (VN) break-down promoting an enhanced cell proliferation, migration and invasion in pancreatic cancer cells [78, 79]. Together, these findings suggest important roles of KLKs not only in normal physiological processes but also in disorders such as, cancer.

\section{Expression of KLKs in ovarian cancer}

In the last decades, numerous studies have determined the aberrant expression of members of the KLK family in ovarian cancer [80-82]. Different groups, including ours, have reported that the majority of the KLKs (KLK4-11, KLK13-K15) are aberrantly expressed in ovarian cancerous, compared to normal and benign tissues [12, 80, 81]. It has been reported that at the transcriptional level, KLK4-8, KLK10 and KLK14 are highly expressed in ovarian cancer tissues. Importantly, unbiased gene microarray analyses demonstrated an up-regulated transcription of KLK5-8 and KLK10 in EOC [83, 84]. High protein levels of KLK4-7 and KLK10 have been found in ovarian cancer tissues, while KLK5-8, KLK10, KLK11, KLK13 and KLK14 were found in ascites fluid from ovarian cancer patients as reviewed [81, 85, 86]. Interestingly, KLK6 and KLK10 have shown a strong potential as clinical serum biomarkers for this cancer [81].

Of further clinical relevance, high mRNA and/or protein levels of KLK4-7, KLK10 and KLK15 are associated with shorter progression-free and overall survival time of patients [87-92]. Significantly, the up-regulated expression of KLK4-7, KLK10 and KLK15 is associated with high grade 
and late stage disease, belonging to the more aggressive Type-II tumors [87-92]. Interestingly, KLK5-7 expression in EOC tissues displayed a closer association with a larger remaining tumor following surgery, higher grade and later stage disease than CA125 [93], the currently used biomarker for women with this cancer. A recent study demonstrated that the expression of KLK6 in stromal cells was associated with aggressiveness of this disease, suggesting its role in the EOC microenvironment [94]. High serum levels of KLK5 [95, 96], KLK6 [97, 98] and KLK10 [99] were associated with poor outcome in women with EOC, suggesting their potential as alternative biomarkers for this malignancy. KLK6-8 and KLK10 have been found to be more specific than KLK4, KLK5, KLK11, KLK14 and KLK15 in EOC [100] in differentiating between benign and other malignant secretions in ascites and pleural effusion fluid. In addition, we and others have reported that high tumor levels of KLK4 and KLK7 were associated with chemoresistance in patients with this cancer [101-103]. On the other hand, levels of KLK8, KLK9, KLK11, KLK13 and KLK14 in tumor tissues were higher in early stage disease, when optimal debulking surgery had been performed, and in those patients who responded to chemotherapy and had a long survival time [91, 104-106]. Our studies, and those from others, showed that KLK4-8 and KLK10 are expressed at high levels in EOC, in particular in high grade serous EOC [52, 89, 107-109]. A strong correlation within the cluster of kallikreins, KLK5-8, KLK10 and KLK11 in EOC tissue samples has been reported [110] suggesting their co-expression in this disease.

Recent studies using genome-wide microRNA (miRNA) profiling approaches have demonstrated the association between expression of miRNAs with pathogenesis, and their potential assistance in diagnosis and prognosis of ovarian cancer. miRNAs have been shown as tumor suppressors or oncogenes, and can also target different cell signaling pathways [111]. For example, let-7a-2 targets KRAS and IL6 functioning as a tumor suppressor, while miR-21 regulates PTEN as an oncogene. Recent bioinformatics analyses have predicted the potential regulation of KLK peptidases by multiple miRNAs [112]. To confirm these findings, White et al. have shown that transfection of let-7f, miR-224, or miR-516a in EOC OVCAR-3 cells reduced expression of KLK10 at both mRNA and protein levels, and cell proliferation [112]. In addition, transfection of let-7f miRNA significantly decreased KLK6 and KLK10 secretion into conditioned media, indicating that one single miRNA targets multiple KLKs [113]. These studies provide evidence that KLK expression is regulated by miRNAs which have a role in post-transcriptional regulation of KLK peptidases.

Together, differential expression of KLKs not only has potential as EOC biomarkers, but may indicate a critical role of these peptidases in the ovarian cancer microenvironment promoting progression and chemo-resistant metastasis, especially in the aggressive Type-II tumors.

\section{Functions of KLKs in ovarian cancer metastases}

KLKs enhance EOC multicellular aggregation in 3-dimensional (3D) microenvironments

As KLK4 and KLK7 are up-regulated in EOC cells and tumor tissue samples, with high levels associated with poor outcome in women with this disease [87, 102???], we overexpressed these peptidases in SKOV3 EOC cells to determine their function. We found a reduced migration of SKOV 3 cells stably over-expressing KLK4 or KLK7, but no significant changes in cell proliferation in conventional 2-dimensional (2D) monolayer cultures. To investigate the role of these enzymes in the ovarian tumor microenvironment (Fig. 2a) [4, 28], we established a 3-dimensional (3D)suspension culture (Fig. 2b) to mimic the ascites fluid seen in patients [114]. It is known that homotypic cell adhesion promotes cell survival by forming MCAs in the ascitic fluid suspension microenvironment, and we observed the formation of compact MCAs in KLK4-expressing SKOV3 cells, as did SKOV3 cells treated with recombinant active KLK4 [103]. MCA formation was reduced by treatment with a KLK4 blocking antibody or the selective active-site KLK4 sunflower trypsin inhibitor (SFTI-FCQR), further supporting the role of this peptidase in EOC. KLK4expressing SKOV3 cells had high levels of the KLK4 substrate, uPA, particularly in 3D-suspension, and high levels of both KLK4 and uPA were observed in patient cells taken from ascites [103]. Lipocalin 2, also named neutrophil gelatinase-associated lipocalin, has been linked to an EOC phenotype [115], and we showed its induction in KLK4expressing SKOV3 cells and further up-regulation in the 3Dsuspension microenvironment [114].

Similar observations were also made in KLK7expressing SKOV3 cells cultured in 3D-suspension [102] and in the endogenous KLK7 expressing OVCA432 cells (Fig. 2b, left panel). Different from KLK4, however, increased levels of $\alpha 5 / \beta 1$ integrins and enhanced adhesion to $\mathrm{FN}$ and $\mathrm{VN}$, which was inhibited with a $\beta 1$ integrin blocking antibody, were observed. Blocking MCA using antibodies against KLK7, $\alpha 5 \beta 1$ and $\beta 1$ integrins confirmed the involvement of KLK7 and integrin-regulated cell adhesion. Importantly, these MCAs invade into a monolayer of peritoneal mesothelial LP9 cells and form cancer cell foci (Fig. 2b, mid panel). We also found that EOC cells derived from ascites fluid expressed higher levels of KLK7 and $\alpha 5 \beta 1$ integrin compared to their matched primary tumor cells [102]. Our findings suggest a mechanism for the association of high KLK7 levels with poor 


\section{$\begin{array}{lll}\text { A Primary EOC } & \text { Ascites EOC } \\ & & \end{array}$}

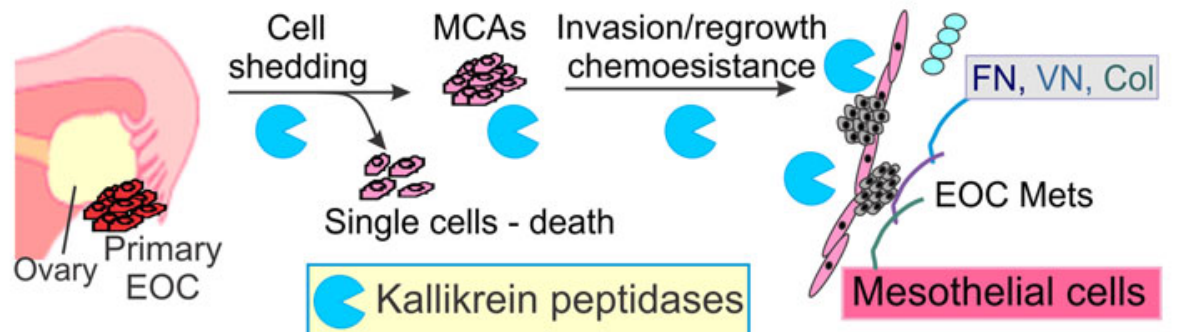

B
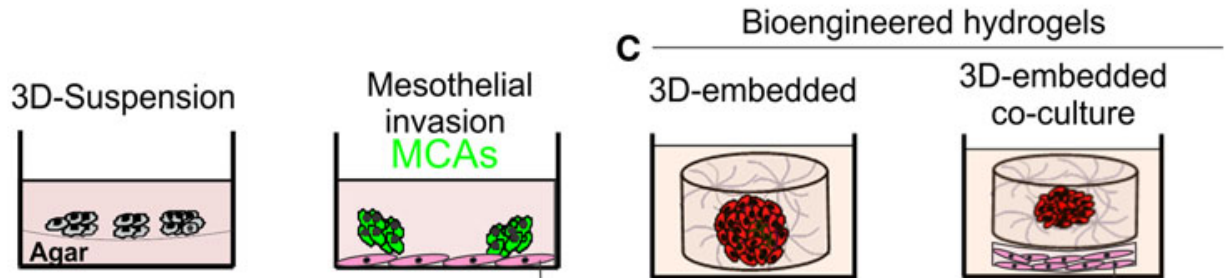

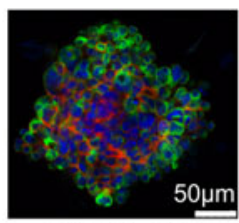

OVCA432 KLK7/F-actin/DAPI

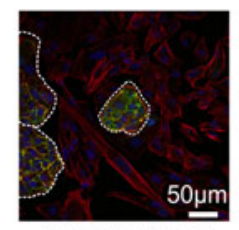

SKOV3-K7 Ecad/F-actin/DAPI
Fig. 2 Cell culture platforms to mimic EOC metastasis. a Schematic diagram showing potential roles of KLKs in EOC peritoneal dissemination. b Top left panel, 3D-suspension cultures to mimic the EOC cells growing in the ascites fluid microenvironment. Top right panel, MCAs invading into a monolayer of mesothelial cells to mimic peritoneal invasion. Bottom left panel, MCAs formed by OVCA432 cells stained with anti-KLK7 and AlexaFluor488 (green), F-actin stained with AlexaFluor568 phalloidin (red), nuclei stained with 4',6-diamidino-2-phenylindole (DAPI, blue). Bottom right panel, invasion into mesothelial cell monolayer by KLK7-expressing SKOV3 cell (SKOV3-K7) MCAs stained with anti-E-Cadherin

prognosis for serous EOC patients by promotion of peritoneal dissemination and invasion via increased MCA formation and $\alpha 5 \beta 1$ integrin-mediated cell adhesion. These findings suggest a role of KLKs in EOC metastasis due to the formation of MCA and peritoneal invasion, but the underlying mechanisms differ as KLK4 acts via uPA whilst KLK7 induced integrin-associated pathways.

As noted as above, an in vitro biochemical feature of the members in the KLK family is an enzymatic cascade between different KLKs [116, 117]; KLK4 activates proKLK6 and proKLK5, KLK5 auto-activates and activates proKLK6 and proKLK7, KLK6 auto-activates and partially activates proKLK5 (Fig. 3). Importantly, parallel expression of these KLKs has been shown in EOC [12], indicating their interacting roles in this disease (Fig. 3). A previous study demonstrated that simultaneous over- expression of KLK4, KLK5, KLK6 and KLK7 (KLK4-7) in OV-MZ-6 EOC cells significantly increased their invasive behavior in an in vitro transwell Matrigel assay [118]. These KLK4-7 expressing OV-MZ-6 cells increased tumor growth in an animal model compared to OV-MZ-6 cells expressing the single KLK4, KLK5, KLK6 or KLK7, or vector controls. To explore the underlying mechanism, our group has recently reported that KLK4-7 expressing OVMZ-6 cells had reduced levels of $\alpha 5 \beta 1$ and $\alpha v \beta 3$ integrins, leading to reduced adhesion to the ECM proteins FN and VN [119].

To understand the crucial mechanism underlying the interaction between EOC cells and their extracellular microenvironment, we have employed a bioengineered hydrogel platform [120] (Fig. 3c). This 3D platform comprises synthetic protease-sensitive hydrogels that are 


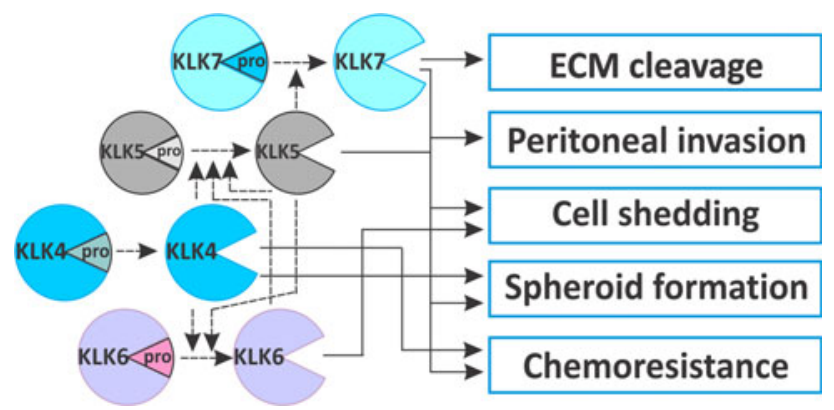

Fig. 3 Schematic diagram showing the biochemical activation cascade of KLK4, KLK5, KLK6 and KLK7 (dashed lines) and their roles in different aspects of ovarian cancer metastasis (continuous lines). ECM extracellular matrix

formed from peptide-functionalized polyethylene glycol macromolecules via a factor XIII-catalysed reaction, similar to the fibrinogen cross-linking that occurs during natural fibrin coagulation [121, 122]. Interestingly, overexpression of KLK4-7 did not alter the proliferation rate of OV-MZ-6 EOC cells when cultured as conventional 2D monolayers [118]. However, KLK4-7 expressing OV-MZ6 cells formed more and larger spheroids when cultured in 3D bioengineered matrices $[114,123]$. In particular, a much higher growth rate of KLK4-7 expressing spheroids was seen when they were co-cultured with mesothelial cells, implying their growth-promoting effect on EOC cells [114]. Together, we have demonstrated that KLK peptidases promoted EOC cell survival, MCA formation, adhesion to ECM proteins and invasion into the peritoneal microenvironment, ultimately leading to metastasis.

\section{Chemoresistance is mediated by KLK proteases in EOC}

Chemoresistance is a major obstacle to overcome for prolonging the survival time of women with EOC. A previous study showed that high levels of KLK10 (also known as the normal epithelial cell-specific 1, NES1) in tumor tissue predicted tamoxifen resistance in breast cancer patients [124]. An early study showed that expression of KLK4 in ovarian cancer tissues is associated with resistance to a first line, clinically-used chemo-agent paclitaxel in EOC patients [125]. We have recently confirmed this finding [103] and also demonstrated that high levels of KLK7 in tumor tissues are associated with chemoresistance in EOC patients [102]. It has been documented that MCAs, representing a 3D architecture, are more resistant than 2D monolayer cells [126], and compact MCAs are less responsive to various treatments, including chemotherapies, than scattered and small MCAs [127]. In in vitro studies, we observed that KLK4, but not KLK7-expressing SKOV3 cells are more resistant to cisplatin in 2D monolayer cultures [102, 103]. However, MCAs formed by either KLK4 or KLK7 expressing SKOV3 cells are less responsive to paclitaxel than the vector and native control cells when cultured in 3D-suspension as MCAs. Interestingly, adding the KLK4 selective SFTI-FCQR not only reduced the compaction of KLK4-expressing MCAs but importantly increased their response to paclitaxel to a greater degree than the general serine protease inhibitor, aprotinin [103]. Lipocalin 2, has been associated with chemoresistance $[128,129]$ and is up-regulated in KLK4 expressing SKOV3 cells cultured as MCAs in 3D suspension [114]. Furthermore, KLK4-7 expressing OV-MZ-6 cells were less responsive to paclitaxel, but not carboplatin, in both 2D monolayers and 3D bioengineered matrices [119]. In search of the underlying mechanism, we reported that the reduced paclitaxel response is independent of MAPK signaling [119]. Interestingly, the levels of $\alpha 5 \beta 1$ and $\alpha v \beta 3$ integrins decreased in KLK4-7-expressing OVMZ- 6 cells, but adding paclitaxel increased the level of $\alpha 5$ integrin, suggesting its role in paclitaxel resistance induced by these four KLKs $[114,119]$. These data imply the potential of inhibition of KLK action as part of a combined therapeutic approach for EOC patients, especially those with high KLK levels in their tumors.

\section{Proteolytic functions of KLKs in ovarian cancer} metastasis

In vitro biochemical studies demonstrated that KLK enzymes function via extracellular hydrolysis or proteolytic activity, such as cleavage of cell-cell adhesion proteins, membrane bound proteins and receptors, cytokines and growth factors, ECM proteins, and proteases including KLKs. For example, KLK4-7 regulate the break-down of the ECM proteins fibronectin (FN), VN, laminin and TypeI and IV collagens [63, 130-134]. All these proteins form part of the ECM that underlies the mesothelial cell layer lining the abdominal cavity which is the most common EOC metastatic site $[135,136]$. The cleaved ECM products can contribute to an altered cellular phenotype and cell function, promoting migration and invasion of EOC cells leading to the establishment of metastasis [137-139]. It has been reported that MMP2 cleaves FN and VN into small fragments and increases binding of EOC cells to these fragments and their receptors $\alpha 5 \beta 1$ and $\alpha 3 \beta 1$ integrins promoting peritoneal adhesion and invasion [136]. It has also been documented that FN is a substrate of KLK7 [134] and we showed that KLK7 over-expression in SKOV3 EOC cells induced their adhesion to this substrate and the level of its receptor $\alpha 5 \beta 1$ integrins increased [102]. In addition to the ECM components, proteases can also be substrates of KLK enzymes. KLK4 can cleave uPA, to generate its active form, and also its receptor UPAR [70, 140], both known to be induced in EOC cells in the ascites fluid [141], and associated with chemoresistance and poor 
prognosis in patients with EOC $[142,143]$. KLK7 can cleave the cytokine interleukin (IL)-1 $\beta$ converting it to its active form [144] which can modify the morphology of mesothelial cells, allowing EOC cells to invade into the ECM beneath the peritoneal membrane [145]. KLK6 [146] and KLK7 [78] cleave the cell adhesion protein E-cadherin generating shed fragments which are at a high level in metastatic EOC and ascites [137]. Interestingly, loss of E-cadherin has been associated with EOC progression, parallel to MMP9 [11] which is also a substrate of KLK7 [69]. These data generated from patient samples in clinical studies, along with their biochemical activity, implicate KLKs in the progression and chemoresistance of metastatic EOC.

Non-proteolytic functions of KLKs in ovarian cancer

Although KLK peptidases function via extracellular hydrolysis to exhibit their enzymatic activity, recent studies have shown their non-proteolytic function in ovarian cancer both in vitro and in vivo. In the KLK gene family, more than 80 splicing variant transcripts have been identified $[147,148]$. We have previously reported the simultaneous expression of the wild type transcript encoding the full-length KLK7 and the mRNA variant for an N-terminal truncated KLK7-181 protein in EOC but not in normal ovarian epithelial cells [107]. In later functional studies, we observed that similarly to wild type KLK7, KLK7-181expressing SKOV3 cells showed increased adhesion to the ECM proteins FN and VN, formed compact MCAs and were more resistant to paclitaxel treatment, suggesting a role of this KLK7-181 variant which is not enzymatically active [102]. We have also found that active KLK4 enzyme treated SKOV3 cells formed compact spheroids that were larger than those treated with the non-active mutant KLK4 (serine to alanine mutation at catalytic triad) which in turn were slightly larger than those seen for vector and native control cells [103]. These data indicate that the action of KLK4 in MCA formation involves both proteolytic and non-proteolytic effects. In addition, KLK10 (NES1) was identified from breast cancer cells but is down-regulated in the progression of EOC [149]. Over-expression of KLK10 in ES2 EOC cells reduced their anchorage-independent growth in vitro and caused a smaller tumor burden in an animal model compared to vector controls [150]. Adding recombinant KLK10 protein into cultures confirmed these findings, supporting its role as a tumor suppressor in EOC progression both in vitro and in vivo. However, the recombinant KLK10 added lacked catalytic activity, indicating a non-proteolytic function in the progression of this disease. These findings are consistent with an earlier study in which two blocking antibodies against PSA/KLK3, one inhibiting the enzymatic activity and the other one not affecting the catalytic activity, both inhibited the biological function of this KLK, suggesting that PSA also has an alternative action via protein-protein interactions [151].

In summary, we have reviewed recent studies on the role of kallikrein peptidases in ovarian cancer progression and resistance to chemotherapy. Importantly, our findings and those of others have provided evidence that both 3D-suspension models and bioengineered matrices can successfully be used as in vitro 3D platforms for research into the functional roles of KLK enzymes on ovarian cancer metastasis and chemoresistance.

\section{Future directions}

For the past decade, our understanding of ovarian cancer progression and chemo-resistant metastasis has been steadily increasing, including our knowledge of the roles of cancer-associated proteases, such as KLKs. To investigate the roles of KLKs in the development, progression, and in particular the chemo-resistant metastasis of ovarian tumors, we have developed in vitro cell culture platforms that closely mimic the in vivo microenvironment. However, we still face challenges to improve these platforms to examine the function of KLK proteases specifically in different EOC microenvironments. In addition, some KLK enzymes have shown potential as pharmaceutical targets while other KLKs may have potential as part of combined therapeutic approaches. Of note, recent studies have shown the potential of synthetic small inhibitors to target individual KLK enzymes at in vitro biochemical and cellular levels $[43,44,152]$. We are still at an early stage testing the antimetastatic potential of KLK inhibitors using these 3D platforms, and more effort is needed in developing these assays for application to patient derived tumor cells. Furthermore, how interactions in vitro between postulated proteolytic cascades involving different KLK proteases occurs in biological tissues and other related factors and/or contributors occur remains largely unknown. Therefore, we endeavor to identify the biological substrates of the ovarian cancer associated KLK peptidases and their regulated signaling networks in order to identify the underlying molecular mechanisms and molecular targets. Our increasing knowledge will enable further efforts in search of the most effective approaches to target KLK action in the tumor microenvironment, improving the survival time of women with this cancer as well as their quality of life.

Acknowledgments National Health and Medical Research Council (NHMRC) of Australia Grant 550523 (JAC, YD), Australia-India Strategic Research Fund BF060023 (JAC, YD), the Cancer Council of Queensland (JAC, DL), Wesley Research Foundation 2010-07 (JLN, YD, JAC, AO), Institute of Health and Biomedical Innovation, Queensland University of Technology (DL, HIR, JAC, YD). JAC and 
HIR are NHMRC Principal and Training Research Fellows respectively.

Conflict of interest No potential conflicts of interest are disclosed.

Open Access This article is distributed under the terms of the Creative Commons Attribution License which permits any use, distribution, and reproduction in any medium, provided the original author(s) and the source are credited.

\section{References}

1. AIHW (2010) Ovarian cancer in Australia: an overview. cancer. Australian Institute of Health and Welfare, Canberra

2. Cancer-Research-UK., 2011 Ovarian cancer survival statistics

3. Siegel R, Naishadham D, Jemal A (2013) Cancer statistics. CA Cancer J Clin 63:11-30

4. Tan DS, Agarwal R, Kaye SB (2006) Mechanisms of transcoelomic metastasis in ovarian cancer. Lancet Oncol 7:925-934

5. Ozols RF, Bundy BN, Greer BE, Fowler JM, Clarke-Pearson D, Burger RA, Mannel RS, DeGeest K, Hartenbach EM, Baergen R (2003) Phase III trial of carboplatin and paclitaxel compared with cisplatin and paclitaxel in patients with optimally resected stage III ovarian cancer: a gynecologic oncology group study. J Clin Oncol 21:3194-3200

6. Bast RC Jr, Hennessy B, Mills GB (2009) The biology of ovarian cancer: new opportunities for translation. Nat Rev Cancer 9:415-428

7. Greenlee RT, Hill-Harmon MB, Murray T, Thun M (2001) Cancer statistics. CA Cancer J Clin 51:15-36

8. Fishman DA, Borzorgi K (2002) Cancer treatment and research in "Ovarian cancer". Kluwer, Boston, pp 3-28

9. Kwon Y, Cukierman E, Godwin AK (2011) Differential expressions of adhesive molecules and proteases define mechanisms of ovarian tumor cell matrix penetration/invasion. PLoS One 6:18872

10. Torng PL, Mao TL, Chan WY, Huang SC, Lin CT (2004) Prognostic significance of stromal metalloproteinase-2 in ovarian adenocarcinoma and its relation to carcinoma progression. Gynecol Oncol 92:559-567

11. Cowden Dahl KD, Symowicz J, Ning Y, Gutierrez E, Fishman DA, Adley BP, Stack MS, Hudson LG (2008) Matrix metalloproteinase 9 is a mediator of epidermal growth factor-dependent e-cadherin loss in ovarian carcinoma cells. Cancer Res 68:4606-4613

12. Yousef GM, Polymeris ME, Yacoub GM, Scorilas A, Soosaipillai A, Popalis C, Fracchioli S, Katsaros D, Diamandis EP (2003) Parallel overexpression of seven kallikrein genes in ovarian cancer. Cancer Res 63:2223-2227

13. Clements JA, Willemsen NM, Myers M, Dong Y (2004) The tissue kallikrein family of serine proteases: functional roles in human disease and potential as clinical biomarkers. Crit Rev Clin Lab Sci 41:265-312

14. Lee Y, Miron A, Drapkin R, Nucci MR, Medeiros F, Saleemuddin A, Garber J, Birch C, Mou H, Gordon RW, Cramer DW, McKeon FD, Crum CP (2007) A candidate precursor to serous carcinoma that originates in the distal fallopian tube. J Pathol 211:26-35

15. Piek JM, van Diest PJ, Zweemer RP, Jansen JW, Poort-Keesom RJ, Menko FH, Gille JJ, Jongsma AP, Pals G, Kenemans P, Verheijen RH (2001) Dysplastic changes in prophylactically removed fallopian tubes of women predisposed to developing ovarian cancer. J Pathol 195:451-456
16. Piek JM, Verheijen RH, van Diest PJ (2009) Tubal and ovarian pathways to pelvic epithelial cancer: a pathological perspective. Histopathology 54:494-495

17. Kurman RJ, Shih Ie M (2010) The origin and pathogenesis of epithelial ovarian cancer: a proposed unifying theory. Am J Surg Pathol 34:433-443

18. Shih Ie M, Kurman RJ (2004) Ovarian tumorigenesis: a proposed model based on morphological and molecular genetic analysis. Am J Pathol 164:1511-1518

19. Singer G, Oldt R 3rd, Cohen Y, Wang BG, Sidransky D, Kurman RJ, Shih Ie M (2003) Mutations in BRAF and KRAS characterize the development of low-grade ovarian serous carcinoma. J Natl Cancer Inst 95:484-486

20. Mok SC, Bell DA, Knapp RC, Fishbaugh PM, Welch WR, Muto MG, Berkowitz RS, Tsao SW (1993) Mutation of K-ras protooncogene in human ovarian epithelial tumors of borderline malignancy. Cancer Res 53:1489-1492

21. Sieben NL, Macropoulos P, Roemen GM, Kolkman-Uljee SM, Jan Fleuren G, Houmadi R, Diss T, Warren B, Al Adnani M, De Goeij AP, Krausz T, Flanagan AM (2004) In ovarian neoplasms, BRAF, but not KRAS, mutations are restricted to low-grade serous tumours. J Pathol 202:336-340

22. Kurman RJ, Shih Ie M (2011) Molecular pathogenesis and extraovarian origin of epithelial ovarian cancer-shifting the paradigm. Hum Pathol 42:918-931

23. Bowtell DD (2010) The genesis and evolution of high-grade serous ovarian cancer. Nat Rev Cancer 10:803-808

24. Tcga RN (2011) Integrated genomic analyses of ovarian carcinoma. Nature 474:609-615

25. Ghosh S, Wu Y, Stack (2002) Ovarian Cancer-associated proteinases. In: Stack, Fishman DA (eds) Cancer treatment and research: ovarian cancer. Kluwer, Boston, pp 331-354

26. Puls LE, Duniho T, Hunter JE, Kryscio R, Blackhurst D, Gallion $\mathrm{H}$ (1996) The prognostic implication of ascites in advancedstage ovarian cancer. Gynecol Oncol 61:109-112

27. Kipps E, Tan DS, Kaye SB (2013) Meeting the challenge of ascites in ovarian cancer: new avenues for therapy and research. Nat Rev Cancer 13:273-282

28. Shield K, Ackland ML, Ahmed N, Rice GE (2009) Multicellular spheroids in ovarian cancer metastases: biology and pathology. Gynecol Oncol 113:143-148

29. Latifi A, Luwor RB, Bilandzic M, Nazaretian S, Stenvers K, Pyman J, Zhu H, Thompson EW, Quinn MA, Findlay JK, Ahmed N (2012) Isolation and characterization of tumor cells from the ascites of ovarian cancer patients: molecular phenotype of chemoresistant ovarian tumors. PLoS One 7:46858

30. Hooper JD, Bui LT, Rae FK, Harvey TJ, Myers SA, Ashworth LK, Clements JA (2001) Identification and characterization of KLK14, a novel kallikrein serine protease gene located on human chromosome $19 \mathrm{q} 13.4$ and expressed in prostate and skeletal muscle. Genomics 73:117-122

31. Stephenson SA, Verity K, Ashworth LK, Clements JA (1999) Localization of a new prostate-specific antigen-related serine protease gene, KLK4, is evidence for an expanded human kallikrein gene family cluster on chromosome 19q13.3-13.4. J Biol Chem 274:23210-23214

32. Harvey TJ, Hooper JD, Myers SA, Stephenson SA, Ashworth LK, Clements JA (2000) Tissue-specific expression patterns and fine mapping of the human kallikrein (KLK) locus on proximal 19q13.4. J Biol Chem 275:37397-37406

33. Yousef GM, Chang A, Scorilas A, Diamandis EP (2000) Genomic organization of the human kallikrein gene family on chromosome 19q13.3-q13.4. Biochem Biophys Res Commun 276:125-133

34. Gan L, Lee I, Smith R, Argonza-Barrett R, Lei H, McCuaig J, Moss P, Paeper B, Wang K (2000) Sequencing and expression 
analysis of the serine protease gene cluster located in chromosome 19q13 region. Gene 257:119-130

35. Lundwall A, Clauss A, Olsson AY (2006) Evolution of kallikrein-related peptidases in mammals and identification of a genetic locus encoding potential regulatory inhibitors. Biol Chem 387:243-249

36. Debela M, Beaufort N, Magdolen V, Schechter NM, Craik CS, Schmitt M, Bode W, Goettig P (2008) Structures and specificity of the human kallikrein-related peptidases KLK 4, 5, 6, and 7. Biol Chem 389:623-632

37. Yoon H, Blaber SI, Debela M, Goettig P, Scarisbrick IA, Blaber M (2009) A completed KLK activome profile: investigation of activation profiles of KLK9, 10, and 15. Biol Chem 390:373-377

38. Lawrence MG, Lai J, Clements JA (2010) Kallikreins on steroids: structure, function, and hormonal regulation of prostatespecific antigen and the extended kallikrein locus. Endocr Rev 31:407-446

39. Sotiropoulou G, Pampalakis G, Diamandis EP (2009) Functional roles of human kallikrein-related peptidases. J Biol Chem 284:32989-32994

40. Borgono CA, Diamandis EP (2004) The emerging roles of human tissue kallikreins in cancer. Nat Rev Cancer 4:876-890

41. Yoon H, Blaber SI, Li W, Scarisbrick IA, Blaber M (2013) Activation profiles of human kallikrein-related peptidases by matrix metalloproteinases. Biol Chem 394:137-147

42. Laskowski M, Qasim MA (2000) What can the structures of enzyme-inhibitor complexes tell us about the structures of enzyme substrate complexes? Biochim Biophys Acta 1477:324-337

43. Goettig P, Magdolen V, Brandstetter H (2010) Natural and synthetic inhibitors of kallikrein-related peptidases (KLKs). Biochimie 92:1546-1567

44. Swedberg JE, de Veer SJ, Harris JM (2009) Natural and engineered kallikrein inhibitors: an emerging pharmacopeia. Biol Chem 16:433-443

45. Swedberg JE, Nigon LV, Reid JC, de Veer SJ, Walpole CM, Stephens CR, Walsh TP, Takayama TK, Hooper JD, Clements JA, Buckle AM, Harris JM (2009) Substrate-guided design of a potent and selective kallikrein-related peptidase inhibitor for kallikrein 4. Chem Biol 16:633-643

46. Swedberg JE, de Veer SJ, Sit KC, Reboul CF, Buckle AM, Harris JM (2011) Mastering the canonical loop of serine protease inhibitors: enhancing potency by optimising the internal hydrogen bond network. PLoS One 6:19302

47. de Veer SJ, Ukolova SS, Munro CA, Swedberg JE, Buckle AM, Harris JM (2013) Mechanism-based selection of a potent kallikrein-related peptidase 7 inhibitor from a versatile library based on the sunflower trypsin inhibitor SFTI-1. Biopolymers. doi:10. 1002/peps.22231

48. Shaw JL, Diamandis EP (2007) Distribution of 15 human kallikreins in tissues and biological fluids. Clin Chem 53:1423-1432

49. Stanbrough M, Bubley GJ, Ross K, Golub TR, Rubin MA, Penning TM, Febbo PG, Balk SP (2006) Increased expression of genes converting adrenal androgens to testosterone in androgenindependent prostate cancer. Cancer Res 66:2815-2825

50. Myers SA, Clements JA (2001) Kallikrein 4 (KLK4), a new member of the human kallikrein gene family is up-regulated by estrogen and progesterone in the human endometrial cancer cell line. J Clin Endocrinol Metab 86:2323-2326

51. Lai J, Myers SA, Lawrence MG, Odorico DM, Clements JA (2009) Direct progesterone receptor and indirect androgen receptor interactions with the kallikrein-related peptidase 4 gene promoter in breast and prostate cancer. Mol Cancer Res 7:129-141

52. Dong Y, Kaushal A, Bui L, Chu S, Fuller PJ, Nicklin J, Samaratunga $\mathrm{H}$, Clements JA (2001) Human kallikrein 4 (KLK4) is highly expressed in serous ovarian carcinomas. Clin Cancer Res 7:2363-2371
53. Marcondes S, Antunes E (2005) The plasma and tissue kininogen-kallikrein-kinin system: role in the cardiovascular system. Curr Med Chem Cardiovasc Hematol Agents 3:33-44

54. Bartlett JD, Simmer JP, Ryu OH, Fincham AG, Hu CC, Zhang C, Qian Q (1999) Proteinases in developing dental enamel: characterization of recombinant pig enamelysin activity and cleavage of recombinant pig and mouse amelogenins. Crit Rev Oral Biol Med 10:425-441

55. Yamakoshi Y, Hu JC, Fukae M, Yamakoshi F, Simmer JP (2006) How do enamelysin and kallikrein 4 process the $32-\mathrm{kDa}$ enamelin? Eur J Oral Sci 114:379-380

56. Hart PS, Hart TC, Michalec MD, Ryu OH, Simmons D, Hong S, Wright JT (2004) Mutation in kallikrein 4 causes autosomal recessive hypomaturation amelogenesis imperfecta. J Med Genet 41:545-549

57. Becker-Pauly C, Howel M, Walker T, Vlad A, Aufenvenne K, Oji V, Lottaz D, Sterchi EE, Debela M, Magdolen V, Traupe H, Stocker W (2007) The alpha and beta subunits of the metalloprotease meprin are expressed in separate layers of human epidermis, revealing different functions in keratinocyte proliferation and differentiation. J Invest Dermatol 127:1115-1125

58. Ohler A, Debela M, Wagner S, Magdolen V, Becker-Pauly C (2010) Analyzing the protease web in skin: meprin metalloproteases are activated specifically by KLK4, 5 and 8 vice versa leading to processing of proKLK7 thereby triggering its activation. Biol Chem 391:455-460

59. Simon M, Jonca N, Guerrin M, Haftek M, Bernard D, Caubet C, Egelrud T, Schmidt R, Serre G (2001) Refined characterization of corneodesmosin proteolysis during terminal differentiation of human epidermis and its relationship to desquamation. J Biol Chem 276:20292-20299

60. Brattsand M, Stefansson K, Lundh C, Haasum Y, Egelrud T (2005) A proteolytic cascade of kallikreins in the stratum corneum. J Invest Dermatol 124:198-203

61. Caubet C, Jonca N, Brattsand M, Guerrin M, Bernard D, Schmidt R, Egelrud T, Simon M, Serre G (2004) Degradation of corneodesmosome proteins by two serine proteases of the kallikrein family, SCTE/KLK5/hK5 and SCCE/KLK7/hK7. J Invest Dermatol 122:1235-1244

62. Little SP, Dixon EP, Norris F, Buckley W, Becker GW, Johnson M, Dobbins JR, Wyrick T, Miller JR, MacKellar W, Hepburn D, Corvalan J, McClure D, Liu X, Stephenson D, Clemens J, Johnstone EM (1997) Zyme, a novel and potentially amyloidogenic enzyme cDNA isolated from Alzheimer's disease brain. J Biol Chem 272:25135-25142

63. Magklara A, Mellati AA, Wasney GA, Little SP, Sotiropoulou G, Becker GW, Diamandis EP (2003) Characterization of the enzymatic activity of human kallikrein 6: autoactivation, substrate specificity, and regulation by inhibitors. Biochem Biophys Res Commun 307:948-955

64. Ogawa K, Yamada T, Tsujioka Y, Taguchi J, Takahashi M, Tsuboi Y, Fujino Y, Nakajima M, Yamamoto T, Akatsu H, Mitsui S, Yamaguchi N (2000) Localization of a novel type trypsin-like serine protease, neurosin, in brain tissues of Alzheimer's disease and Parkinson's disease. Psychiatry Clin Neurosci 54:419-426

65. Scarisbrick IA, Yoon H, Panos M, Larson N, Blaber SI, Blaber M, Rodriguez M (2012) Kallikrein 6 regulates early CNS demyelination in a viral model of multiple sclerosis. Brain Pathol 22:709-722

66. Lilja H, Ulmert D, Vickers AJ (2008) Prostate-specific antigen and prostate cancer: prediction, detection and monitoring. Nat Rev Cancer 8:268-278

67. Cohen P, Graves HC, Peehl DM, Kamarei M, Giudice LC, Rosenfeld RG (1992) Prostate-specific antigen (PSA) is an insulin-like growth factor binding protein-3 protease found in seminal plasma. J Clin Endocrinol Metab 75:1046-1053 
68. Rehault S, Monget P, Mazerbourg S, Tremblay R, Gutman N, Gauthier F, Moreau T (2001) Insulin-like growth factor binding proteins (IGFBPs) as potential physiological substrates for human kallikreins $\mathrm{hK} 2$ and $\mathrm{hK} 3$. Eur $\mathrm{J}$ Biochem 268:2960-2968

69. Ramani VC, Kaushal GP, Haun RS (2011) Proteolytic action of kallikrein-related peptidase 7 produces unique active matrix metalloproteinase-9 lacking the C-terminal hemopexin domains. Biochim Biophys Acta 1813:1525-1531

70. Beaufort N, Debela M, Creutzburg S, Kellermann J, Bode W, Schmitt M, Pidard D, Magdolen V (2006) Interplay of human tissue kallikrein 4 (hK4) with the plasminogen activation system: hK4 regulates the structure and functions of the urokinasetype plasminogen activator receptor (uPAR). Biol Chem 387:217-222

71. Schmitt M, Mengele K, Napieralski R, Magdolen V, Reuning U, Gkazepis A, Sweep F, Brunner N, Foekens J, Harbeck N (2010) Clinical utility of level-of-evidence-1 disease forecast cancer biomarkers uPA and its inhibitor PAI-1. Expert Rev Mol Diagn 10:1051-1067

72. Magdolen V, Kruger A, Sato S, Nagel J, Sperl S, Reuning U, Rettenberger P, Magdolen U, Schmitt M (2003) Inhibition of the tumor-associated urokinase-type plasminogen activation system: effects of high-level synthesis of soluble urokinase receptor in ovarian and breast cancer cells in vitro and in vivo. Recent Results Cancer Res 162:43-63

73. Oikonomopoulou K, Hansen KK, Saifeddine M, Tea I, Blaber M, Blaber SI, Scarisbrick I, Andrade-Gordon P, Cottrell GS, Bunnett NW, Diamandis EP, Hollenberg MD (2006) Proteinaseactivated receptors, targets for kallikrein signaling. J Biol Chem 281:32095-32112

74. Ramsay AJ, Reid JC, Adams MN, Samaratunga H, Dong Y, Clements JA, Hooper JD (2008) Prostatic trypsin-like kallikreinrelated peptidases (KLKs) and other prostate-expressed tryptic proteinases as regulators of signalling via proteinase-activated receptors (PARs). Biol Chem 389:653-668

75. Gao L, Chao L, Chao J (2010) A novel signaling pathway of tissue kallikrein in promoting keratinocyte migration: activation of proteinase-activated receptor 1 and epidermal growth factor receptor. Exp Cell Res 316:376-389

76. Ramsay AJ, Dong Y, Hunt ML, Linn M, Samaratunga H, Clements JA, Hooper JD (2008) Kallikrein-related peptidase 4 (KLK4) initiates intracellular signaling via protease-activated receptors (PARs). KLK4 and PAR-2 are co-expressed during prostate cancer progression. J Biol Chem 283:12293-12304

77. Xi Z, Klokk TI, Korkmaz K, Kurys P, Elbi C, Risberg B, Danielsen H, Loda M, Saatcioglu F (2004) Kallikrein 4 is a predominantly nuclear protein and is overexpressed in prostate cancer. Cancer Res 64:2365-2370

78. Johnson SK, Ramani VC, Hennings L, Haun RS (2007) Kallikrein 7 enhances pancreatic cancer cell invasion by shedding E-cadherin. Cancer 109:1811-1820

79. Ramani VC, Haun RS (2008) Expression of kallikrein 7 diminishes pancreatic cancer cell adhesion to vitronectin and enhances urokinase-type plasminogen activator receptor shedding. Pancreas 37:399-404

80. Paliouras M, Borgono C, Diamandis EP (2007) Human tissue kallikreins: the cancer biomarker family. Cancer Lett 249:61-79

81. Yousef GM, Diamandis EP (2009) The human kallikrein gene family: new biomarkers for ovarian cancer. In: Stack MS, Fishman DA (eds) Ovarian cancer. Springer, New York, pp 165-188

82. Schmitt M, Magdolen V (2009) Using kallikrein-related peptidases (KLK) as novel cancer biomarkers. Thromb Haemost 101:222-224

83. Hibbs K, Skubitz KM, Pambuccian SE, Casey RC, Burleson KM, Oegema TR Jr, Thiele JJ, Grindle SM, Bliss RL, Skubitz
AP (2004) Differential gene expression in ovarian carcinoma: identification of potential biomarkers. Am J Pathol 165:397-414

84. Santin AD, Zhan F, Bellone S, Palmieri M, Cane S, Bignotti E, Anfossi S, Gokden M, Dunn D, Roman JJ, O'Brien TJ, Tian E, Cannon MJ, Shaughnessy J Jr, Pecorelli S (2004) Gene expression profiles in primary ovarian serous papillary tumors and normal ovarian epithelium: identification of candidate molecular markers for ovarian cancer diagnosis and therapy. Int J Cancer 112:14-25

85. Dorn J, Bayani J, Yousef GM, Yang F, Magdolen V, Kiechle M, Diamandis EP, Schmitt M (2013) Clinical utility of kallikreinrelated peptidases (KLK) in urogenital malignancies. Thromb Haemost 110:408-422

86. Dorn J, Milou V, Kulasingam V, Schmalfeldt B, Diamandis EP, Schmitt M (2012) Clinical relevance of kallikrein-related peptidases in ovarian cancer. In: Magdolen V, Sommerhoff C, Fritz H, Schmitt M (eds) Kallikrein-related peptidases. DeGruyter, Berlin, pp 145-166

87. Obiezu CV, Scorilas A, Katsaros D, Massobrio M, Yousef GM, Fracchioli S, De Rigault La Longrais IA, Arisio R, Diamandis EP (2001) Higher human kallikrein gene 4 (KLK4) expression indicates poor prognosis of ovarian cancer patients. Clin Cancer Res 7:2380-2386

88. Luo LY, Katsaros D, Scorilas A, Fracchioli S, Piccinno R, De Rigault la Longrais IA, Howarth DJ, Diamandis EP (2001) Prognostic value of human kallikrein 10 expression in epithelial ovarian carcinoma. Clin Cancer Res 7:2372-2379

89. Shvartsman HS, Lu KH, Lee J, Lillie J, Deavers MT, Clifford S, Wolf JK, Mills GB, Bast RC Jr, Gershenson DM, Schmandt R (2003) Overexpression of kallikrein 10 in epithelial ovarian carcinomas. Gynecol Oncol 90:44-50

90. Yousef GM, Scorilas A, Katsaros D, Fracchioli S, Iskander L, Borgono C, De Rigault la Longrais IA, Puopolo M, Massobrio M, Diamandis EP (2003) Prognostic value of the human kallikrein gene 15 expression in ovarian cancer. J Clin Oncol 21:3119-3126

91. Scorilas A, Borgono CA, Harbeck N, Dorn J, Schmalfeldt B, Schmitt M, Diamandis EP (2004) Human kallikrein 13 protein in ovarian cancer cytosols: a new favorable prognostic marker. J Clin Oncol 22:678-685

92. Borgono CA, Fracchioli S, Yousef GM, de Rigault la Longrais IA, Luo LY, Soosaipillai A, Puopolo M, Grass L, Scorilas A, Diamandis EP, Katsaros D (2003) Favorable prognostic value of tissue human kallikrein 11 (hK11) in patients with ovarian carcinoma. Int J Cancer 106:605-610

93. Zheng Y, Katsaros D, Shan SJ, de la Longrais IR, Porpiglia M, Scorilas A, Kim NW, Wolfert RL, Simon I, Li L, Feng Z, Diamandis EP (2007) A multiparametric panel for ovarian cancer diagnosis, prognosis, and response to chemotherapy. Clin Cancer Res 13:6984-6992

94. Seiz L, Dorn J, Kotzsch M, Walch A, Grebenchtchikov NI, Gkazepis A, Schmalfeldt B, Kiechle M, Bayani J, Diamandis EP, Langer R, Sweep FC, Schmitt M, Magdolen V (2012) Stromal cell-associated expression of kallikrein-related peptidase 6 (KLK6) indicates poor prognosis of ovarian cancer patients. Biol Chem 393:391-401

95. Bandiera E, Zanotti L, Bignotti E, Romani C, Tassi R, Todeschini P, Tognon G, Ragnoli M, Santin AD, Gion M, Pecorelli S, Ravaggi A (2009) Human kallikrein 5: an interesting novel biomarker in ovarian cancer patients that elicits humoral response. Int J Gynecol Cancer 19:1015-1021

96. Dorn J, Harbeck N, Kates R, Gkazepis A, Scorilas A, Soosaipillai A, Diamandis E, Kiechle M, Schmalfeldt B, Schmitt M (2010) Impact of expression differences of kallikrein-related peptidases and of UPA and PAI-1 between primary tumor and omentum metastasis in advanced ovarian cancer. Ann Oncol 22:877-883 
97. Diamandis EP, Scorilas A, Fracchioli S, Van Gramberen M, De Bruijn H, Henrik A, Soosaipillai A, Grass L, Yousef GM, Stenman UH, Massobrio M, Van Der Zee AG, Vergote I, Katsaros D (2003) Human kallikrein 6 (hK6): a new potential serum biomarker for diagnosis and prognosis of ovarian carcinoma. J Clin Oncol 21:1035-1043

98. Diamandis EP, Yousef GM, Soosaipillai AR, Bunting P (2000) Human kallikrein 6 (zyme/protease M/neurosin): a new serum biomarker of ovarian carcinoma. Clin Biochem 33:579-583

99. Luo LY, Katsaros D, Scorilas A, Fracchioli S, Bellino R, van Gramberen M, de Bruijn H, Henrik A, Stenman UH, Massobrio M, van der Zee AG, Vergote I, Diamandis EP (2003) The serum concentration of human kallikrein 10 represents a novel biomarker for ovarian cancer diagnosis and prognosis. Cancer Res 63:807-811

100. Shih Ie M, Salani R, Fiegl M, Wang TL, Soosaipillai A, Marth C, Muller-Holzner E, Gastl G, Zhang Z, Diamandis EP (2007) Ovarian cancer specific kallikrein profile in effusions. Gynecol Oncol 105:501-507

101. Bhan V, Mader JS, Hoskin DW (2004) In vitro exposure to paclitaxel modulates integrin expression by human $\mathrm{T}$ lymphocytes and inhibits $\mathrm{T}$ cell adhesion to breast carcinoma cells. Oncol Rep 11:893-897

102. Dong Y, Tan OL, Loessner D, Stephens C, Walpole C, Boyle GM, Parsons PG, Clements JA (2010) Kallikrein-related peptidase 7 promotes multicellular aggregation via the alpha(5)beta(1) integrin pathway and paclitaxel chemoresistance in serous epithelial ovarian carcinoma. Cancer Res 70:2624-2633

103. Dong Y, Stephens C, Walpole C, Swedberg JE, Boyle GM, Parsons PG, McGuckin MA, Harris JM, Clements JA (2013) Paclitaxel resistance and multicellular spheroid formation are induced by kallikrein-related peptidase 4 in serous ovarian cancer cells in an ascites mimicking microenvironment. PLoS One 8:57056

104. Yousef GM, Kyriakopoulou LG, Scorilas A, Fracchioli S, Ghiringhello B, Zarghooni M, Chang A, Diamandis M, Giardina G, Hartwick WJ, Richiardi G, Massobrio M, Diamandis EP, Katsaros D (2001) Quantitative expression of the human kallikrein gene 9 (KLK9) in ovarian cancer: a new independent and favorable prognostic marker. Cancer Res 61:7811-7818

105. Borgono CA, Grass L, Soosaipillai A, Yousef GM, Petraki CD, Howarth DH, Fracchioli S, Katsaros D, Diamandis EP (2003) Human kallikrein 14: a new potential biomarker for ovarian and breast cancer. Cancer Res 63:9032-9041

106. Shigemasa K, Tian X, Gu L, Tanimoto H, Underwood LJ, O'Brien TJ, Ohama K (2004) Human kallikrein 8 (hK8/TADG14) expression is associated with an early clinical stage and favorable prognosis in ovarian cancer. Oncol Rep 11:1153-1159

107. Dong Y, Kaushal A, Brattsand M, Nicklin J, Clements JA (2003) Differential splicing of KLK5 and KLK7 in epithelial ovarian cancer produces novel variants with potential as cancer biomarkers. Clin Cancer Res 9:1710-1720

108. Tanimoto H, Underwood LJ, Shigemasa K, Parmley TH, O'Brien TJ (2001) Increased expression of protease $M$ in ovarian tumors. Tumour Biol 22:11-18

109. Underwood LJ, Tanimoto H, Wang Y, Shigemasa K, Parmley TH, O’Brien TJ (1999) Cloning of tumor-associated differentially expressed gene-14, a novel serine protease overexpressed by ovarian carcinoma. Cancer Res 59:4435-4439

110. Dorn J, Harbeck N, Kates R, Magdolen V, Grass L, Soosaipillai A, Schmalfeldt B, Diamandis EP, Schmitt M (2006) Disease processes may be reflected by correlations among tissue kallikrein proteases but not with proteolytic factors uPA and PAI-1 in primary ovarian carcinoma. Biol Chem 387:1121-1128

111. Di Leva G, Croce CM (2013) The role of microRNAs in the tumorigenesis of ovarian cancer. Front Oncol 3:153
112. White NM, Chow TF, Mejia-Guerrero S, Diamandis M, Rofael Y, Faragalla H, Mankaruous M, Gabril M, Girgis A, Yousef GM (2010) Three dysregulated miRNAs control kallikrein 10 expression and cell proliferation in ovarian cancer. Br J Cancer 102:1244-1253

113. Chow TF, Crow M, Earle T, El-Said H, Diamandis EP, Yousef GM (2008) Kallikreins as microRNA targets: an in silico and experimental-based analysis. Biol Chem 389:731-738

114. Dong Y, Loessner D, Sieh S, Taubenberger A, Fuhrman-Luck RA, Magdolen V, Hutmacher DW, Clements JA (2012) Cellular model systems to study the tumor biological role of kallikreinrelated peptidases in ovarian and prostate cancer. In: Magdolen S, Schmitt, Fritz (eds) Kallikrein-related peptidases: novel cancer-related biomarkers. De Gruyter, Berlin, pp 83-110

115. Lim R, Ahmed N, Borregaard N, Riley C, Wafai R, Thompson EW, Quinn MA, Rice GE (2007) Neutrophil gelatinase-associated lipocalin (NGAL) an early-screening biomarker for ovarian cancer: nGAL is associated with epidermal growth factor-induced epithelio-mesenchymal transition. Int J Cancer 120:2426-2434

116. Yoon H, Laxmikanthan G, Lee J, Blaber SI, Rodriguez A, Kogot JM, Scarisbrick IA, Blaber M (2007) Activation profiles and regulatory cascades of the human kallikrein-related peptidases. J Biol Chem 282:31852-31864

117. Beaufort N, Plaza K, Utzschneider D, Schwarz A, Burkhart JM, Creutzburg S, Debela M, Schmitt M, Ries C, Magdolen V (2010) Interdependence of kallikrein-related peptidases in proteolytic networks. Biol Chem 391:581-587

118. Prezas P, Arlt MJ, Viktorov P, Soosaipillai A, Holzscheiter L, Schmitt M, Talieri M, Diamandis EP, Kruger A, Magdolen V (2006) Overexpression of the human tissue kallikrein genes KLK4, 5, 6, and 7 increases the malignant phenotype of ovarian cancer cells. Biol Chem 387:807-811

119. Loessner D, Quent VM, Kraemer J, Weber EC, Hutmacher DW, Magdolen V, Clements JA (2012) Combined expression of KLK4, KLK5, KLK6, and KLK7 by ovarian cancer cells leads to decreased adhesion and paclitaxel-induced chemoresistance. Gynecol Oncol 127:569-578

120. Loessner D, Stok KS, Lutolf MP, Hutmacher DW, Clements JA, Rizzi SC (2010) Bioengineered 3D platform to explore cellECM interactions and drug resistance of epithelial ovarian cancer cells. Biomaterials 31:8494-8506

121. Rizzi SC, Ehrbar M, Halstenberg S, Raeber GP, Schmoekel HG, Hagenmuller H, Muller R, Weber FE, Hubbell JA (2006) Recombinant protein-co-PEG networks as cell-adhesive and proteolytically degradable hydrogel matrixes. Part II: biofunctional characteristics. Biomacromolecules 7:3019-3029

122. Rizzi SC, Hubbell JA (2005) Recombinant protein-co-PEG networks as cell-adhesive and proteolytically degradable hydrogel matrixes. Part I: Development and physicochemical characteristics. Biomacromolecules 6:1226-1238

123. Loessner D, Flegg JA, Byrne HM, Clements JA, Hutmacher DW (2013) Growth of confined cancer spheroids: a combined experimental and mathematical modelling approach. Integr Biol (Camb) 5:597-605

124. Luo LY, Diamandis EP, Look MP, Soosaipillai AP, Foekens JA (2002) Higher expression of human kallikrein 10 in breast cancer tissue predicts tamoxifen resistance. $\mathrm{Br} \mathrm{J}$ Cancer 86:1790-1796

125. Xi Z, Kaern J, Davidson B, Klokk TI, Risberg B, Trope C, Saatcioglu F (2004) Kallikrein 4 is associated with paclitaxel resistance in ovarian cancer. Gynecol Oncol 94:80-85

126. Frankel A, Buckman R, Kerbel RS (1997) Abrogation of taxolinduced G2-M arrest and apoptosis in human ovarian cancer cells grown as multicellular tumor spheroids. Cancer Res 57:2388-2393

127. Minchinton AI, Tannock IF (2006) Drug penetration in solid tumours. Nat Rev Cancer 6:583-592 
128. Li SH, Hawthorne VS, Neal CL, Sanghera S, Xu J, Yang J, Guo H, Steeg PS, Yu D (2009) Upregulation of neutrophil gelatinaseassociated lipocalin by ErbB2 through nuclear factor-kappaB activation. Cancer Res 69:9163-9168

129. Stewart JJ, White JT, Yan X, Collins S, Drescher CW, Urban ND, Hood L, Lin B (2006) Proteins associated with Cisplatin resistance in ovarian cancer cells identified by quantitative proteomic technology and integrated with mRNA expression levels. Mol Cell Proteomics 5:433-443

130. Ghosh MC, Grass L, Soosaipillai A, Sotiropoulou G, Diamandis EP (2004) Human kallikrein 6 degrades extracellular matrix proteins and may enhance the metastatic potential of tumour cells. Tumour Biol 25:193-199

131. Michael IP, Sotiropoulou G, Pampalakis G, Magklara A, Ghosh M, Wasney G, Diamandis EP (2005) Biochemical and enzymatic characterization of human kallikrein 5 (hK5), a novel serine protease potentially involved in cancer progression. J Biol Chem 280:14628-14635

132. Obiezu CV, Michael IP, Levesque MA, Diamandis EP (2006) Human kallikrein 4: enzymatic activity, inhibition, and degradation of extracellular matrix proteins. Biol Chem 387:749-759

133. Matsumura M, Bhatt AS, Andress D, Clegg N, Takayama TK, Craik CS, Nelson PS (2005) Substrates of the prostate-specific serine protease prostase/KLK4 defined by positional-scanning peptide libraries. Prostate 62:1-13

134. Ramani VC, Haun RS (2008) The extracellular matrix protein fibronectin is a substrate for kallikrein 7. Biochem Biophys Res Commun 369:1169-1173

135. Witz CA, Montoya-Rodriguez IA, Cho S, Centonze VE, Bonewald LF, Schenken RS (2001) Composition of the extracellular matrix of the peritoneum. J Soc Gynecol Investig 8:299-304

136. Kenny HA, Kaur S, Coussens LM, Lengyel E (2008) The initial steps of ovarian cancer cell metastasis are mediated by MMP-2 cleavage of vitronectin and fibronectin. $\mathrm{J}$ Clin Invest 118:1367-1379

137. Symowicz J, Adley BP, Gleason KJ, Johnson JJ, Ghosh S, Fishman DA, Hudson LG, Stack MS (2007) Engagement of collagen-binding integrins promotes matrix metalloproteinase-9dependent E-cadherin ectodomain shedding in ovarian carcinoma cells. Cancer Res 67:2030-2039

138. Moss NM, Barbolina MV, Liu Y, Sun L, Munshi HG, Stack MS (2009) Ovarian cancer cell detachment and multicellular aggregate formation are regulated by membrane type 1 matrix metalloproteinase: a potential role in I.p. metastatic dissemination. Cancer Res 69:7121-7129

139. Liotta LA, Tryggvason K, Garbisa S, Hart I, Foltz CM, Shafie S (1980) Metastatic potential correlates with enzymatic degradation of basement membrane collagen. Nature 284:67-68

140. Takayama TK, McMullen BA, Nelson PS, Matsumura M, Fujikawa K (2001) Characterization of hK4 (prostase), a prostate- specific serine protease: activation of the precursor of prostate specific antigen (pro-PSA) and single-chain urokinase-type plasminogen activator and degradation of prostatic acid phosphatase. Biochemistry 40:15341-15348

141. Ahmed N, Riley C, Oliva K, Rice G, Quinn M (2005) Ascites induces modulation of alpha6betal integrin and urokinase plasminogen activator receptor expression and associated functions in ovarian carcinoma. Br J Cancer 92:1475-1485

142. Chen H, Hao J, Wang L, Li Y (2009) Coexpression of invasive markers (uPA, CD44) and multiple drug-resistance proteins (MDR1, MRP2) is correlated with epithelial ovarian cancer progression. Br J Cancer 101:432-440

143. Kuhn W, Schmalfeldt B, Reuning U, Pache L, Berger U, Ulm K, Harbeck N, Spathe K, Dettmar P, Hofler H, Janicke F, Schmitt M, Graeff H (1999) Prognostic significance of urokinase (uPA) and its inhibitor PAI-1 for survival in advanced ovarian carcinoma stage FIGO IIIc. Br J Cancer 79:1746-1751

144. Nylander-Lundqvist E, Egelrud T (1997) Formation of active IL-1 beta from pro-IL-1 beta catalyzed by stratum corneum chymotryptic enzyme in vitro. Acta Derm Venereol 77:203-206

145. Stadlmann S, Pollheimer J, Renner K, Zeimet AG, Offner FA, Amberger A (2006) Response of human peritoneal mesothelial cells to inflammatory injury is regulated by interleukin-1beta and tumor necrosis factor-alpha. Wound Repair Regen 14:187-194

146. Klucky B, Mueller R, Vogt I, Teurich S, Hartenstein B, Breuhahn K, Flechtenmacher C, Angel P, Hess J (2007) Kallikrein 6 induces E-cadherin shedding and promotes cell proliferation, migration, and invasion. Cancer Res 67:8198-8206

147. Kurlender L, Borgono C, Michael IP, Obiezu C, Elliott MB, Yousef GM, Diamandis EP (2005) A survey of alternative transcripts of human tissue kallikrein genes. Biochim Biophys Acta 1755:1-14

148. Tan OL, Whitbread AK, Clements JA, Dong Y (2006) Kallikrein-related peptidase (KLK) family mRNA variants and protein isoforms in hormone-related cancers: do they have a function? Biol Chem 387:697-705

149. Liu XL, Wazer DE, Watanabe K, Band V (1996) Identification of a novel serine protease-like gene, the expression of which is down-regulated during breast cancer progression. Cancer research 56:3371-3379

150. Pepin D, Shao ZQ, Huppe G, Wakefield A, Chu CW, Sharif Z, Vanderhyden BC (2011) Kallikreins 5, 6 and 10 differentially alter pathophysiology and overall survival in an ovarian cancer xenograft model. PLoS One 6:26075

151. Sun XY, Donald SP, Phang JM (2001) Testosterone and prostate-specific antigen stimulate generation of reactive oxygen species in prostate cancer cells. Carcinogenesis 22:1775-1780

152. Sotiropoulou G, Pampalakis G (2012) Targeting the kallikreinrelated peptidases for drug development. Trends Pharmacol Sci 33:623-634 